\title{
Modelling the kinetics of peroxidase inactivation, colour and texture changes of pumpkin (Cucurbita maxima L.) during blanching
}

\author{
E.M. Gonçalves ${ }^{a, 1}$, J. Pinheiro ${ }^{a, 1}$, M. Abreu ${ }^{a, 1}$, T.R.S. Brandão ${ }^{b, 2}$, C.L.M. Silva ${ }^{b, *, 2}$ \\ ${ }^{a}$ Departamento de Tecnologia das Indústrias Alimentares, Instituto Nacional de Engenharia, Tecnologia e Inovação, \\ Estrada do Paço do Lumiar, 22, 1649-038 Lisboa, Portugal \\ ${ }^{\mathrm{b}}$ Escola Superior de Biotecnologia, Universidade Católica Portuguesa, Rua Dr. António Bernardino de Almeida, 4200-072 Porto, Portugal
}

Keywords: Pumpkin; Blanching; Kinetic models; Peroxidase; Colour; Texture

\begin{abstract}
The effects of blanching treatment on peroxidase inactivation, colour and texture of pumpkin (Cucurbita maxima L.) were studied in the temperature range of $75-95^{\circ} \mathrm{C}$.

Peroxidase inactivation followed a first-order Arrhenius model, where the activation energy and rate of the reaction at a reference temperature of $85^{\circ} \mathrm{C}$ were $86.20 \pm 5.57 \mathrm{~kJ} \mathrm{~mol}^{-1}$ and $0.27 \pm 0.01 \mathrm{~min}^{-1}$, respectively.

During blanching, pumpkin became darker and softer with processing time. The degradation of colour (evaluated throughout CIE $L^{*} a^{*} b^{*}$ colour system, with chroma index and total colour difference) and texture parameters (firmness and energy) showed a fractional conversion model kinetics, being the temperature effect on kinetic parameters well described by the Arrhenius law.

The results of this work are a good tool to further optimise pumpkin blanching conditions.
\end{abstract}

\section{Introduction}

Pumpkin, originated from America, is a member of the family Cucurbitaceae, which also includes squash, cantaloupes, cucumbers, watermelons and gourds. Its shape, size and appearance (smooth or ribbed) vary greatly, depending on species. This fruit, consumed as a vegetable, has great nutritional and health protective values. The bright orange colour indicates that the pumpkin is high in $\beta$-carotene, an important carotenoid. Beta-carotene is an antioxidant precursor to vitamin A in the human body (Weinstein, Vogt, \& Gerrior, 2004).

Pumpkin is very popular in Portuguese cuisine, being acquired in raw fresh pieces and used as a base for soups

\footnotetext{
${ }^{*}$ Corresponding author.

E-mail address: clsilva@esb.ucp.pt (C.L.M. Silva).

${ }^{1}$ Tel.: +351 21 7127153; fax: +351 217127162 .

${ }^{2}$ Tel.: +351 22 5580058; fax: +351225090351.
}

and desserts. Processed pumpkin does not exist in the market. Therefore, canning and freezing, after blanching, may represent a possible method to preserve and commercialize this product.

Blanching is a thermal treatment commonly applied to a variety of vegetables before freezing. Its primary purpose is to inactivate enzymes and destroy vegetative microbial cells, allowing stabilization and product quality retention during frozen storage (Canet, 1989). Blanching affords also a series of secondary benefits, due to its washing action, such as elimination of off-flavors that may have been formed during the time between harvesting and processing, and removal of any residual pesticides (Canet, 1989; Kleinschmidt, 1971; Préstamo, Fuster, \& Risueno, 1998; Shams \& Thompson, 1987).

Blanching, however, has some adverse effects, such as pigment modifications, tissues softening and nutrient losses. Many researchers studied these alterations in different vegetables. Selman (1994), Howard, Wong, Perry, and 


\begin{tabular}{|c|c|c|}
\hline \multicolumn{3}{|c|}{ Nomenclature } \\
\hline$a^{*}$ & $\begin{array}{l}\text { CIE colour space co-ordinate: degree of green- } \\
\text { ness/redness }\end{array}$ & temperature $(\mathrm{K})$ \\
\hline$b^{*}$ & CIE colour space co-ordinate: degree of blue- & Subscripts \\
\hline & ness/yellowness & $0 \quad$ initial (referring to raw product) value \\
\hline$C^{*}$ & chroma index & of the heat-labile fraction \\
\hline$E_{\mathrm{a}}$ & activation energy $\left(\mathrm{J} \mathrm{mol}^{-1}\right)$ & of the heat-resistant fraction \\
\hline$k$ & rate constant $\left(\mathrm{min}^{-1}\right)$ & equilibrium value \\
\hline$L^{*}$ & $\begin{array}{l}\text { CIE colour space co-ordinate: degree of light- } \\
\text { ness }\end{array}$ & $\begin{array}{ll}\text { exp } & \text { experimental value } \\
\text { ref } & \text { reference value }\end{array}$ \\
\hline$P$ & $\begin{array}{l}\text { numerical value of quality factor at time } t \text { (per- } \\
\text { oxidase activity, CIE colour or texture parame- }\end{array}$ & Abbreviations \\
\hline & ters) & HLF heat-labile fraction \\
\hline$R$ & universal gas constant $\left(8.314 \mathrm{~J} \mathrm{~mol}^{-1} \mathrm{~K}^{-1}\right)$ & HRF heat-resistant fraction \\
\hline$t$ & time $(\min )$ & total colour difference \\
\hline
\end{tabular}

Klein (1999), Murcia, López-Ayerra, and Garcia-Carmona (1999) and Oboh (2005) have observed the dramatic blanching effect on the degradation of vegetables nutrient content and antioxidant properties (namely vitamin $\mathrm{C}$ and fatty acids).

The presence of residual endogenous enzymes in processed vegetables may cause quality changes, such as texture, colour, flavor and nutritional losses, during storage. Peroxidase (POD, donor: hydrogen peroxide oxireductase, E.C.1.11.1.7) is an enzyme conventionally used to monitor and evaluate the heat treatment extent, since it is one of the most heat stable enzymes, occurring in a considerable number of vegetables. Even though, its role on quality impact during food storage is not clear yet (Aparicio-Cuesta, Mateos-Notario, \& Rivas-Gonzalo, 1992; Garrote, Luna, Silva, \& Bertone, 1987; Halpin \& Lee, 1987).

Colour is a primary consumer perceived characteristic of a product and plays an important role on food. Furthermore, colour of a processed product is often expected to be as similar as possible to the raw one (MacDougall, 2002). Carotenoids, being the main group of colouring substances in nature, are responsible for many of the red, orange and yellow colours of fruits and vegetables. The stability of carotenoids during processing and storage is crucial for product attractiveness and acceptabilility. Carotenoid degradation affects not only vegetables colour, but also nutritive value and flavor. The common degradation pathways are isomerization, oxidation and fragmentation of the carotenoid molecules, promoted by heat, light and acids (Bonnie \& Choo, 1999; Cinar, 2004). Pigment degradation can be related to physical colour measurements (Bao \& Chang, 1994; Martins \& Silva, 2002; Muftugil, 1986; Sims, Balaban, \& Matthews, 1993).

Texture is another important food quality attribute, defined as a "sensory and functional manifestation of structural, mechanical and surface properties of food, detected through the senses of vision, hearing, touch and kinesthetic" (Szczesniak, 2002). Thermal treatments affect food texture, such as firmness. The thermal impact causes disruption of cell membranes, allowing diffusion of water and low-weight molecules, resulting in turgor loss (Greve et al., 1994) and, consequently, on the development of a rubbery behaviour. However, the most significant softening occurs subsequently as a result of an increase in pectic substances solubilization, loss of turgor pressure, and some degree of cell separation (Chang, Lai, \& Chang, 1995; Galindo, Toledo, \& Sjöholm, 2005; Smout, Sila, Vu, Van Loey, \& Hendrickx, 2005; Waldron, Parker, \& Smith, 2003).

Knowledge on kinetics of enzyme inactivation and quality changes is essential to predict quality losses during blanching time. The most used kinetic models and parameter estimates, for peroxidase inactivation, and colour and texture degradation for a number of fruits and vegetables, are presented in Table 1.

In general, enzyme inactivation and colour changes are well described by zero (Eq. (1)) or first-order models (Eq. (2)) (Anthon \& Barrett, 2002; Ganthavorn, Nagel, \& Powers, 1991; Günes \& Bayindirli, 1993; Lau, Tang, \& Swanson, 2000; Morales-Blancas, Chandia, \& CisnerosZevallos, 2002; Soysal \& Soylemez, 2005; Tijskens, Schijvens, \& Biekman, 2001):

$$
\begin{aligned}
& \frac{P}{P_{0}}=1-k_{(T)} t \\
& \frac{P}{P_{0}}=\mathrm{e}^{-k_{(T)} t}
\end{aligned}
$$

where $P$ is any measured quality factor, the index 0 indicates the initial value, $t$ is the heating time, and $k$ the rate constant at temperature $T$.

Ling and Lund (1978) proposed a biphasic first-order model to describe isoenzyme thermal inactivation kinetics, when different heat-resistant fractions are observed:

$P=P_{01} \mathrm{e}^{-k_{1(T)} t}+P_{02} \mathrm{e}^{-k_{2(T)} t}$ 
Table 1

Published kinetic parameters for the thermal inactivation of peroxidase, and degradation of colour and texture of different fruits and vegetables

\begin{tabular}{|c|c|c|c|c|c|c|}
\hline \multirow[t]{2}{*}{ Quality factor } & \multirow[t]{2}{*}{ Product } & \multirow[t]{2}{*}{ Temperature range $\left({ }^{\circ} \mathrm{C}\right)$} & \multirow[t]{2}{*}{ Kinetic model } & \multicolumn{2}{|l|}{ Kinetic parameters } & \multirow[t]{2}{*}{ Reference } \\
\hline & & & & $\overline{k\left(\min ^{-1}\right)}$ & $E_{\mathrm{a}}\left(\mathrm{kJ} \mathrm{mol}^{-1}\right)$ & \\
\hline \multirow[t]{10}{*}{ Peroxidase inactivation } & Potato & $60-85$ & Arrhenius first order & $560.0_{T=80^{\circ} \mathrm{C}}$ & 478 & Anthon and Barrett (2002) \\
\hline & Tomato (two varieties) & $66-72$ & Arrhenius first order & $1.57 \times 10^{6}$ & 546 & Anthon et al. (2002) \\
\hline & & & & $1.94 \times 10^{6}$ & 557 & \\
\hline & Green beans & $70-95$ & Arrhenius first order & 2.15 & 99.1 & Bifani et al. (2002) \\
\hline & Carrot & $60-85$ & Arrhenius first order & $208.3_{T=80^{\circ} \mathrm{C}}$ & 480 & Anthon and Barrett (2002) \\
\hline & & $35-75$ & Arrhenius biphasic first order & $\begin{array}{l}33,000^{\mathrm{a}}{ }_{T=55^{\circ} \mathrm{C}-\mathrm{HLF}} \\
2000^{\mathrm{a}}{ }_{T=55^{\circ} \mathrm{C}-\mathrm{HRF}}\end{array}$ & $\begin{array}{l}90_{\mathrm{HLF}} \\
148_{\mathrm{HRF}}\end{array}$ & Soysal and Soylemez (2005) \\
\hline & Carrot (cortex) & $70-95$ & Arrhenius biphasic first order & $\begin{array}{l}44,283^{\mathrm{a}} T=80^{\circ} \mathrm{C}-\mathrm{HLF} \\
97^{\mathrm{a}} T=80^{\circ} \mathrm{C}-\mathrm{HRF}\end{array}$ & $\begin{array}{l}95_{\mathrm{HLF}} \\
86_{\mathrm{HRF}}\end{array}$ & Morales-Blancas et al. (2002) \\
\hline & Broccoli & $70-95$ & Arrhenius biphasic first order & $63,485^{\mathrm{a}}{ }_{T=80^{\circ} \mathrm{C}-\mathrm{HLF}}$ & $75_{\mathrm{HLF}}$ & \\
\hline & Asparagus tip & $70-95$ & Arrhenius biphasic first order & $\begin{array}{l}2277^{\mathrm{a}} T=80^{\circ} \mathrm{C}-\mathrm{HRF} \\
69,803^{\mathrm{a}}{ }_{T=80^{\circ} \mathrm{C}-\mathrm{HLF}} \\
280^{\mathrm{a}} T=80^{\circ} \mathrm{C}-\mathrm{HRF}\end{array}$ & $\begin{array}{l}58_{\mathrm{HRF}} \\
67_{\mathrm{HLF}} \\
43_{\mathrm{HRF}}\end{array}$ & \\
\hline & Watercress & $40-92.5$ & Arrhenius biphasic first order & $\begin{array}{l}18_{\mathrm{HLF}} \\
0.24_{\mathrm{HRF}}\end{array}$ & $\begin{array}{l}421_{\mathrm{HLF}} \\
352_{\mathrm{HRF}}\end{array}$ & Cruz et al. (2006) \\
\hline \multirow[t]{9}{*}{ Colour } & $\begin{array}{l}\text { Green chilli puree } \\
\text { Red chilli puree }\end{array}$ & $\begin{array}{l}60-90 \\
60-90\end{array}$ & $\begin{array}{l}\text { Arrhenius first order: } L^{\mathrm{a}} a^{\mathrm{a}} b^{\mathrm{a}} \\
\text { Arrhenius first order: }\end{array}$ & $0.049_{T=60{ }^{\circ} \mathrm{C}}$ & 11.4 & Ahmed et al. (2000) \\
\hline & & & $L^{\mathrm{a}} a^{\mathrm{a}} b^{\mathrm{a}}$ & $0.0107^{\mathrm{a}}$ & 24.8 & \\
\hline & & & $T C D$ & $0.0064^{\mathrm{a}}{ }_{T=80^{\circ} \mathrm{C}}$ & 24.2 & \\
\hline & Tomato paste & $70-100$ & Arrhenius biphasic first order: $L$ & $7.67 \times 10_{\mathrm{HLF}}^{-3}$ & $48.2 \mathrm{HLF}$ & Barreiro et al. (1997) \\
\hline & & & & $1.14 \times 10_{\mathrm{HRF}}^{-3}$ & $24.0_{\mathrm{HRF}}$ & \\
\hline & & & Arrhenius first order: $C$ & $7.29 \times 10^{-3}$ & 42.7 & \\
\hline & Peas & 70_90 & Arrhenius zero order: $T C D$ & 0.24 & 42.3 & \\
\hline & Has & $90-122$ & $\begin{array}{l}\text { Arrhenius first order: } a \\
\text { Arrhenius first order: taste panel }\end{array}$ & $\begin{array}{l}0.009^{\mathrm{a}} T=85^{\circ} \mathrm{C} \\
8.2 \times 10_{T=99{ }^{\circ} \mathrm{C}}^{-3}\end{array}$ & $\begin{array}{l}76.3 \\
85.4\end{array}$ & $\begin{array}{l}\text { Steet and Tong (1996) } \\
\text { Van Loey et al. (1995) }\end{array}$ \\
\hline & Green asparagus & $70-98$ & Arrhenius first order: $a$ & $0.0066_{T=84^{\circ} \mathrm{C}}$ & 54.9 & Lau et al. (2000) \\
\hline \multirow[t]{5}{*}{ Texture } & Green asparagus & $70-98$ & Arrhenius first order: shear stress & $0.016_{T=84{ }^{\circ} \mathrm{C}}$ & 100.6 & Lau et al. (2000) \\
\hline & Peas & $90-122$ & Arrhenius first order: taste panel & $7.8 \times 10_{T=99{ }^{\circ} \mathrm{C}}^{-3}$ & 89.9 & Van Loey et al. (1995) \\
\hline & White beans & $90-122$ & Arrhenius first order: taste panel & $7.6 \times 10_{T=99^{\circ} \mathrm{C}}^{-3}$ & 97.0 & \\
\hline & Carrots & $90-120$ & Arrhenius first order & $150-499^{\mathrm{a}} T=100^{\circ} \mathrm{C}$ & $92-117$ & Paulus and Saguy (1980) \\
\hline & & $80-110$ & $\begin{array}{l}\text { Arrhenius fractional conversion: } \\
\text { firmness }\end{array}$ & $0.147^{\mathrm{a}}{ }_{T=95^{\circ} \mathrm{C}}$ & 117.6 & Vu et al. (2004) \\
\hline
\end{tabular}


The indexes 1 and 2 are indicative of the heat-labile and the heat-resistant fractions, respectively. Morales-Blancas et al. (2002) used this model to describe the thermal inactivation of peroxidase in different vegetables, such as broccoli, green asparagus and carrots.

When any quality parameter varies from an initial value until a residual (or equilibrium) one, which is further retained, the so-called fractional conversion model based on first-order kinetics can be considered:

$\frac{P-P_{\text {eq }}}{P_{0}-P_{\text {eq }}}=\mathrm{e}^{-k_{(T)} t}$

The subscript eq indicates equilibrium value.

Kinetics of vegetables texture alterations due to blanching were studied by different authors: Quast and Da Silva (1977) in black and brown beans, Paulus and Saguy (1980) in carrots, Huang and Bourne (1993) in beetroot and green peas, Bourne (1987) in carrots and green beans, and Kozempel (1988) in potato. Most of the published studies indicated that texture changes during heat treatment follow first-order degradation kinetics. Nevertheless, Rizvi and Tong (1997) proposed the fractional conversion model to describe texture degradation of vegetables. Stoneham, Lund, and Tong (2000) and Vu et al. (2004) also used this model for describing textural changes of potatoes and carrots, respectively.

The temperature dependence of the rate constant is normally described by an Arrhenius behaviour:

$k_{(T)}=k_{\text {ref }} \exp \left[-\frac{E_{\mathrm{a}}}{R}\left(\frac{1}{T}-\frac{1}{T_{\text {ref }}}\right)\right]$

where $k_{\text {ref }}$ is the rate constant at a reference temperature, $T_{\text {ref }}, E_{\text {a }}$ the activation energy, and $R$ the universal gas constant.

The temperature effect can be directly included in quality factors prediction, by substitution of Eq. (5) into kinetic models.

The aim of this study was to evaluate the kinetics of pumpkin peroxidase inactivation and colour and texture changes, during blanching. The results will help to define optimal blanching conditions for maximum quality retention, that will certainly be important for new frozen products development.

\section{Materials and methods}

\section{Sample preparation and blanching process}

Pumpkin (Cucurbita maxima L.), in a fully ripe stage, was obtained in a local market in Lisbon, Portugal, one day after its harvest. The fruit was immediately peeled and cut in cylinders of $50 \mathrm{~mm}$ diameter and $15 \mathrm{~mm}$ height, using a cork borer. Samples ( $400 \mathrm{~g}$ of pumpkin cylinders each) were immersed in a thermostatic water bath $\left( \pm 1^{\circ} \mathrm{C}\right)$, with 501 capacity, at five temperatures $(75,80$, 85,90 and $95^{\circ} \mathrm{C}$ ). During the heat treatments, the temperature of the water and samples was monitored by means of thermocouples (type $\mathrm{T}$ thin thermocouple, $1.2 \mathrm{~mm}$ diameter, embedded in a stainless steel hypodermic needle, Ellab, Denmark, with an accuracy of $\pm 2{ }^{\circ} \mathrm{C}$ ). Depending on the temperature used, samples were collected after different times (not in sequence) till a maximum of $50 \mathrm{~min}$. After blanching, the samples were cooled in an iced water bath for $2 \mathrm{~min}$. Excess moisture was removed before any further analysis.

Each experiment was replicated twice. An unheated sample was taken as a reference.

\section{Peroxidase activity analysis}

Raw and blanched pumpkin samples (20 g each) were weighed into $100 \mathrm{ml}$ of $1 \mathrm{M}$ sodium chloride solution. The samples were homogenized in a blender at $4{ }^{\circ} \mathrm{C}$ for $2 \mathrm{~min}$. The homogenate was centrifuged in polypropylene tubes at $7000 \mathrm{rpm}$, using a Sorvall Instruments RC5C centrifuge, at $4{ }^{\circ} \mathrm{C}$ for $15 \mathrm{~min}$. The slurry was filtered using $1.2 \mu \mathrm{m}$ membrane filters (Whatman). The filtrate was mixed with guaiacol and $\mathrm{H}_{2} \mathrm{O}_{2}$ as substrates. The absorbance increase at $470 \mathrm{~nm}$ was recorded using an UV/vis, ATI Unicam spectrophotometer, based on a modified method of Bifani, Inostroza, Cabezas, and Ihl (2002). The analyses were carried out in duplicate.

The total initial enzyme activity was determined from 10 samples of fresh product.

\section{Measurement of colour}

The colour of pumpkin samples were assessed using a handheld tristimulus colorimeter (Minolta Chroma Meter CR-300, Osaka, Japan) and a CIE standard illuminant C to determine CIE colour space co-ordinates, $L^{*} a^{*} b^{*}$ values (Francis \& Clydesdale, 1975). Lightness value, $L^{*}$, indicates how dark/light the sample is (varying from 0 -black to 100 - white), $a^{*}$ is a measure of greenness/redness (varying from -60 to +60 ), and $b^{*}$ is the grade of blueness/yellowness (also varying from -60 to +60 ). The polar co-ordinate chroma or saturation, $C^{*}$, is an indication of how dull/vivid the product is (ranging from 0 to 60 ), which can be calculated from the $L^{*}, a^{*}$ and $b^{*}$ cartesian co-ordinates by the expression:

$C^{*}=\sqrt{a^{* 2}+b^{* 2}}$

The total colour difference (TCD*) was the parameter considered for the overall colour difference evaluation, between a blanched sample and a raw non-blanched one (indicated by the index 0 in the following equation; Minolta, 1994):

$\mathrm{TCD}^{*}=\sqrt{\left(L_{0}^{*}-L^{*}\right)^{2}+\left(a_{0}^{*}-a^{*}\right)^{2}+\left(b_{0}^{*}-b^{*}\right)^{2}}$

The colorimeter was calibrated against a standard white reference tile. Samples were placed in a clear glass Petri dish (10 replicates), and colour measurements were done in triplicate. 
Texture evaluation

Texture measurements were performed in a TA.HDi Texture Analyser (Stable Micro-System Ltd., Godalming, UK), using a $500 \mathrm{~N}$ load cell and equipped with a $5 \mathrm{~mm}$ diameter probe. A single puncture measurement was made on each sample $(10 \mathrm{~mm}$ depth of penetration, velocity of $1.0 \mathrm{~mm} \mathrm{~s}^{-1}$ ). Force-distance curves were recorded and firmness (maximum peak force, $\mathrm{N}$ ) and energy (area under force-distance curve, J) were used as indicator of textural parameters. At least 12 measurements were done for each conditions tested.

\section{Data analysis}

Rate constants of pumpkin peroxidase inactivation, and colour and texture changes were estimated by non-linear regression analysis, fitting the models of Eqs. (2) and (4) (depending on the parameter considered) to isothermal experimental data. The temperature effect on rate constants was described by the Arrhenius law (Eq. (5)).

The pre-exponential factor and the activation energy were estimated directly from experimental data in one-step (quality factor versus time, at all temperatures), by performing a global non-linear regression analysis, merging the Arrhenius equation and the kinetic models considered (Arabshahi \& Lund, 1985; Lund, 1983). The reference temperature used was the average value of the range considered (i.e. $T_{\text {ref }}=85^{\circ} \mathrm{C}$ ), aiming at improving parameter estimation.

Parameters' precision was evaluated by confidence intervals at $95 \%$, and the quality of the regression was assessed by the coefficient of determination $\left(R^{2}\right)$, and randomness and normality of residuals (Hill \& Grieger-Block, 1980), thus allowing best model selection.

Statistica version 6.0 software (Stata Corp, 1999) was used for all regression analysis procedures (using least squares estimation and Levenverg-Marquart method, for minimising the sum of squares of the deviations between experimental values and the ones predicted by the mathematical model).

An analysis of variance (one-way ANOVA with replication) was performed to assess the blanching time-temperature conditions effects on peroxidase activity, and on colour and texture changes.

\section{Results and discussion}

\section{Peroxidase inactivation}

Typical experimental data of pumpkin peroxidase inactivation, for different times of the blanching processes studied, are shown in Fig. 1 (results are from 80 and $95{ }^{\circ} \mathrm{C}$ ). The values were normalized in relation to specific activity observed in the raw product (i.e. $P / P_{0} \times 100$ ). Specific activity ( \pm standard deviation) of the enzyme in raw pumpkins averaged $1.47 \pm 0.76 \mathrm{Abs} \mathrm{min}^{-1} \mathrm{~g}^{-1}$. The

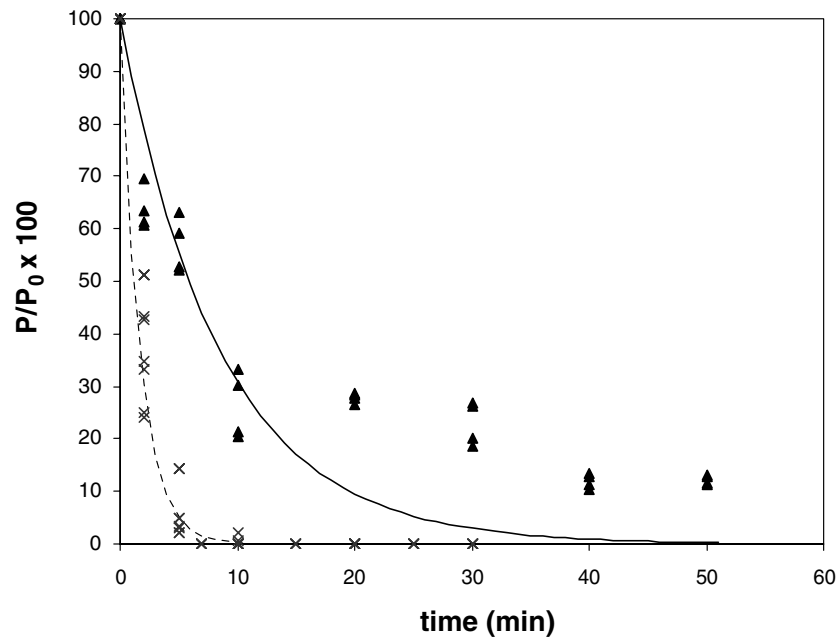

Fig. 1. Pumpkin peroxidase inactivation during blanching process $(\boldsymbol{\Lambda}$ experimental data at $80^{\circ} \mathrm{C} ; \times$ experimental data at $\left.95^{\circ} \mathrm{C}\right)$. The lines represent model fits (Eqs. (2) and (5) one-step) to experimental data.

enzyme inactivation was significantly affected $(P \Leftarrow 0.05)$ by the time and temperature of the blanching process (the higher the temperature, the more efficient the blanching process).

The peroxidase inactivation in different vegetables, such as broccoli, green asparagus, carrots and watercress, has been reported to follow a biphasic first-order model (Cruz, Vieira, \& Silva, 2006; Morales-Blancas et al., 2002). For carrots, potatoes, tomato and green beans, a first-order model was used to describe the enzyme inactivation (Anthon \& Barrett, 2002; Anthon, Sekine, Watanabe, \& Barrett, 2002; Bifani et al., 2002). Experimental results obtained for pumpkin were also satisfactorily described by an Arrhenius first-order kinetic model, for all temperatures tested (an example of model fit obtained by one-step regression analysis is also included in Fig. 1). The quality of the model fit was assessed by analyses of the residuals (i.e. normality and randomness were confirmed). The value of $R^{2}$ was above 0.97 .

Estimated kinetic parameters and confidence intervals at $95 \%$ are in Table $2\left(k_{85}{ }^{\circ} \mathrm{C}=0.27 \pm 0.01 \mathrm{~min}^{-1} ; E_{\mathrm{a}}=\right.$ $86.20 \pm 5.57 \mathrm{~kJ} \mathrm{~mol}^{-1}$ ). A diversity of activation energies of enzymes inactivation kinetics in vegetables are reported in the literature (see Table 1). There is often a lack of information concerning the precision of those estimates. For example Anthon et al. (2002) obtained an activation energy of $557 \mathrm{~kJ} \mathrm{~mol}^{-1}$ for tomato, while Bifani et al. (2002) referred a value of $99.1 \mathrm{~kJ} \mathrm{~mol}^{-1}$ for peroxidase inactivation in green beans.

For optimum quality retention of vegetables during frozen storage, it is recommended a reduction of $90 \%$ of the peroxidase activity, after the blanching treatment (Bahçeci, Serpen, Gökmen, \& Acar, 2005). In the case of blanched pumpkin at 90 and $95^{\circ} \mathrm{C}$, this target reduction was obtained, respectively, after 5.8 and $3.9 \mathrm{~min}$ of the thermal treatment. Günes and Bayindirli (1993), Barret and Theerakulkait (1995) and Bahçeci et al. (2005) 
Table 2

Kinetic parameters and corresponding confidence intervals at $95 \%$ of pumpkin peroxidase inactivation, and colour and texture degradation, due to blanching

\begin{tabular}{|c|c|c|c|c|}
\hline \multirow[t]{2}{*}{ Quality factor (kinetic model) } & \multicolumn{4}{|c|}{ Kinetic parameters } \\
\hline & $P_{0}$ & $P_{\text {eq }}$ & $\mathrm{k}_{85^{\circ} \mathrm{C}}\left(\min ^{-1}\right)$ & $E_{\mathrm{a}}\left(\mathrm{kJ} \mathrm{mol}^{-1}\right)$ \\
\hline Peroxidase inactivation (Arrhenius first order; Eqs. (2) and (5)) & - & - & $0.27 \pm 0.01$ & $86.20 \pm 5.57$ \\
\hline$L^{*}$ & $58.70 \pm 0.25$ & $42.30 \pm 0.25$ & $0.12 \pm 0.01$ & $120.31 \pm 4.63$ \\
\hline$a^{*}$ & $26.90 \pm 0.20$ & $12.30 \pm 0.18$ & $0.12 \pm 0.01$ & $117.94 \pm 3.84$ \\
\hline$b^{*}$ & $54.82 \pm 0.35$ & $35.80 \pm 0.31$ & $0.15 \pm 0.01$ & $110.97 \pm 5.57$ \\
\hline \multicolumn{5}{|l|}{ Texture (Arrhenius fractional conversion; Eqs. (4) and (5)) } \\
\hline Firmness (N) & $63.29 \pm 0.85$ & $6.02 \pm 0.41$ & $0.39 \pm 0.02$ & $72.21 \pm 5.17$ \\
\hline Energy $(\mathrm{J})$ & $0.280 \pm 0.003$ & $0.023 \pm 0.003$ & $0.18 \pm 0.01$ & $101.93 \pm 4.50$ \\
\hline
\end{tabular}

observed an identical effect on peas at $96^{\circ} \mathrm{C}$ after $12 \mathrm{~min}$, and on green beans at 90 and $93.3^{\circ} \mathrm{C}$ after 3 and 2 min, respectively.

\section{Colour changes}

Non-blanched pumpkin (the reference raw sample) exhibited a light yellow colour, corresponding to the following average values ( \pm standard deviation) of the co-ordinates: $L_{0}^{*}=59.48 \pm 2.02 ; \quad a_{0}^{*}=26.58 \pm 1.01 ; \quad b_{0}^{*}=$
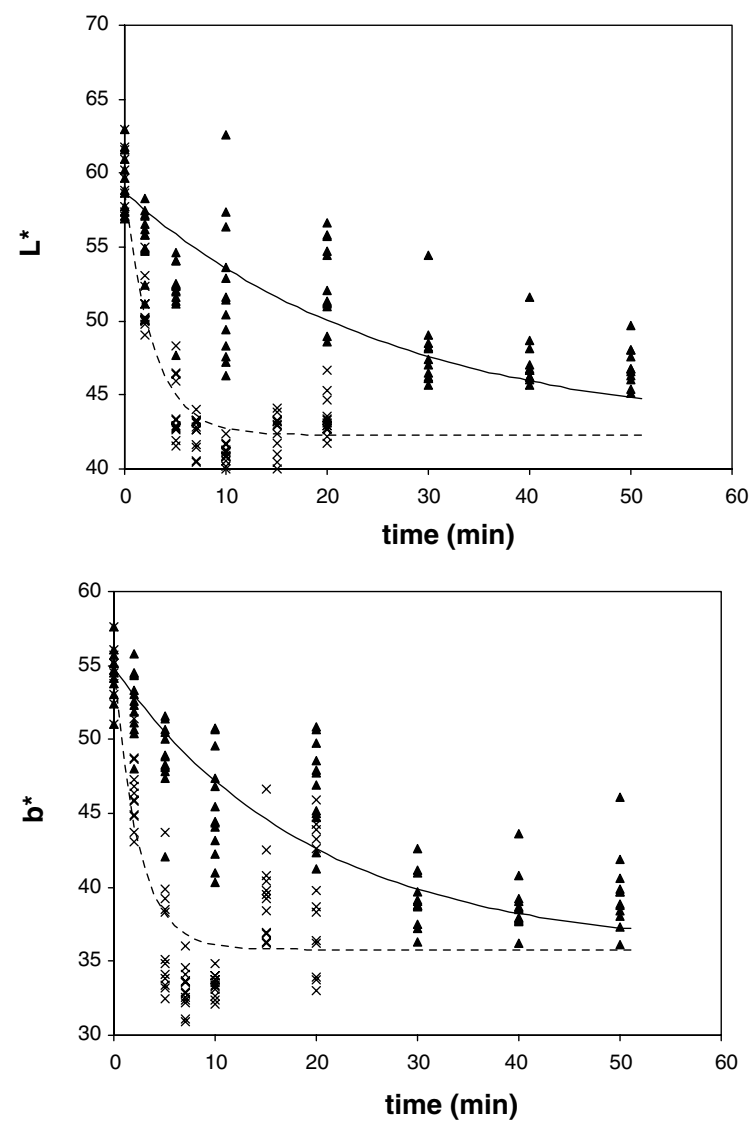

$54.45 \pm 1.71 ; C_{0}^{*}=60.60 \pm 1.73$. For blanched pumpkins, CIE $L^{*} a^{*} b^{*}$ and $C^{*}$ colour factors decreased significantly $(P \Leftarrow 0.05)$ as the time of process and temperature increased (see Fig. 2). The samples became darker, and lost redness, yellowness and vivid characteristics. These colour alterations may be explained by heat carotenoid degradation, as stated by Bao and Chang (1994) and Sims et al. (1993) for carrots, by Barreiro, Milano, and Sandoval (1997) for double concentrated tomato past, and by Ávila and Silva (1999) for peach puree.
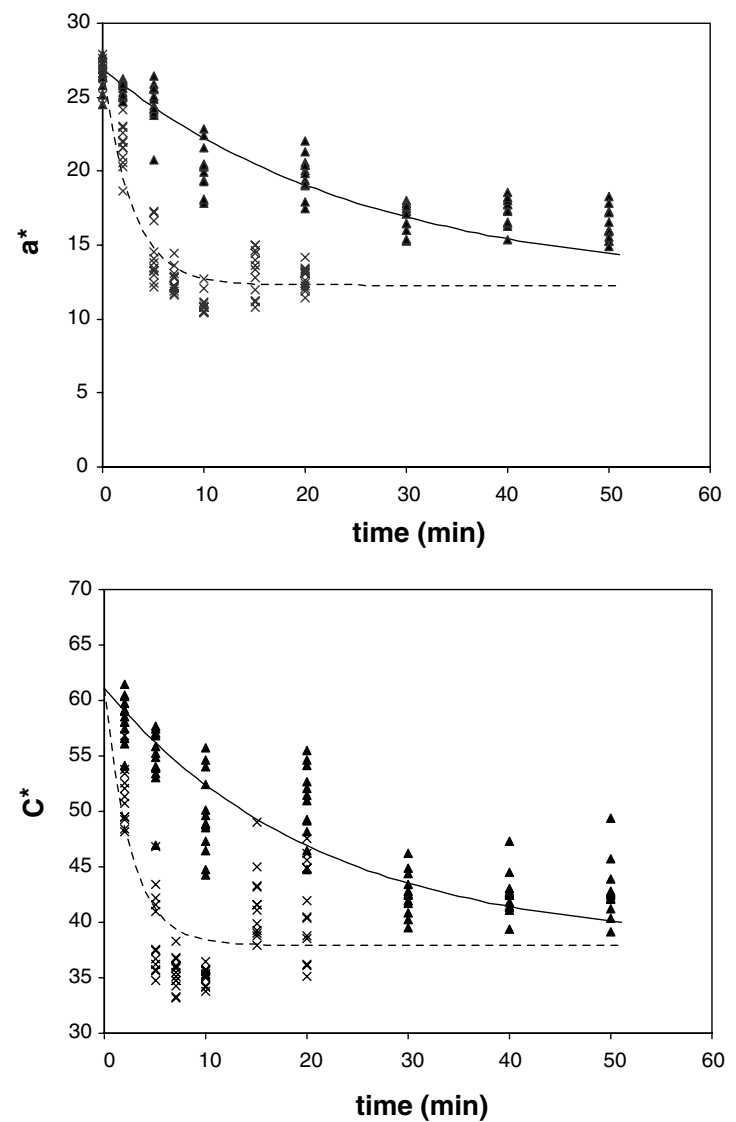

Fig. 2. Pumpkin colour degradation $\left(L^{*} a^{*} b^{*}\right.$ and $C^{*}$ parameters) during blanching process $\left(\boldsymbol{\Delta}\right.$ experimental data at $75^{\circ} \mathrm{C} ; \times$ experimental data at $\left.95^{\circ} \mathrm{C}\right)$. The lines represent model fits (Eqs. (4) and (5) one-step) to experimental data. 
An Arrhenius fractional conversion model (Eqs. (4) and (5)) was successfully fitted to experimental data of $L^{*} a^{*} b^{*}$ and $C^{*}$ (see examples in Fig. 2; estimated parameters and regression analysis results are included in Table 2). For TCD* changes, Eq. (4) was modified to describe an increasing behaviour. Examples of experimental $\mathrm{TCD}^{*}$ data and model fits can be observed in Fig. 3. In all cases normality and randomness of residuals were verified, and coefficient of determination, $R^{2}$, was satisfactorily high, averaging 0.92 ( $\min 0.91-\max 0.94$, values).

Estimated activation energies, rate constants at the reference temperature of $85^{\circ} \mathrm{C}$, and corresponding $95 \%$ confidence intervals of pumpkin colour factors are included in Table 2. Obtained activation energies are considerably high, which is indicative that pumpkin is sensitive to the temperature of the blanching process.

If the blanching conditions proposed to inactivate $90 \%$ of pumpkin peroxidase activity $\left(90^{\circ} \mathrm{C}\right.$ for $5.8 \mathrm{~min}$ or $95^{\circ} \mathrm{C}$ for $3.9 \mathrm{~min}$ ) were considered, colour factors would suffer the following variation in relation to raw product: $L^{*}$ varied $20 \%$ and $25 \%, a^{*}$ varied $38 \%$ and $48 \%, b^{*} 27 \%$ and $32 \%$ and $C^{*} 29 \%$ and $34 \%$, respectively for both conditions. These variations correspond to great differences in the TCD* classification scale (Drlange, 1994).

\section{Texture changes}

Firmness and energy average values $( \pm$ standard deviation) of raw pumpkin were $65.21 \pm 12.40 \mathrm{~N}$ and $0.277 \pm$ $0.050 \mathrm{~J}$, respectively.

Thermal treatment significantly reduced the pumpkin firmness and energy. These textural parameters decreased as process time and temperature increased, tending to an equilibrium value (see examples of experimental data in Fig. 4).

An Arrhenius fraction conversion kinetics model was satisfactorily fitted to experimental data for the degrada-

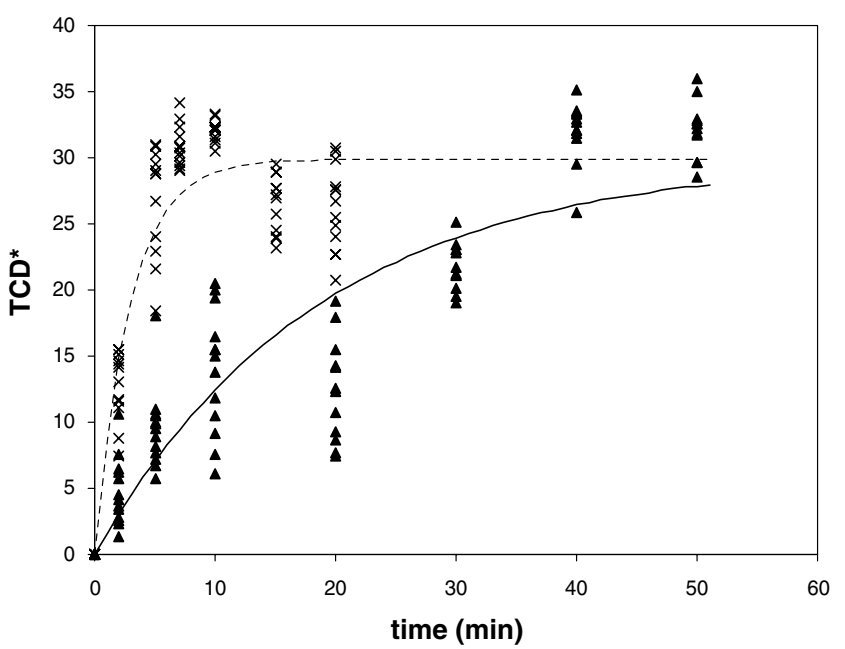

Fig. 3. Pumpkin total colour difference $\left(\mathrm{TCD}^{*}\right)$ during blanching process (ム experimental data at $75^{\circ} \mathrm{C} ; \times$ experimental data at $95^{\circ} \mathrm{C}$ ). The lines represent model fits (Eqs. (4) and (5) one-step) to experimental data.
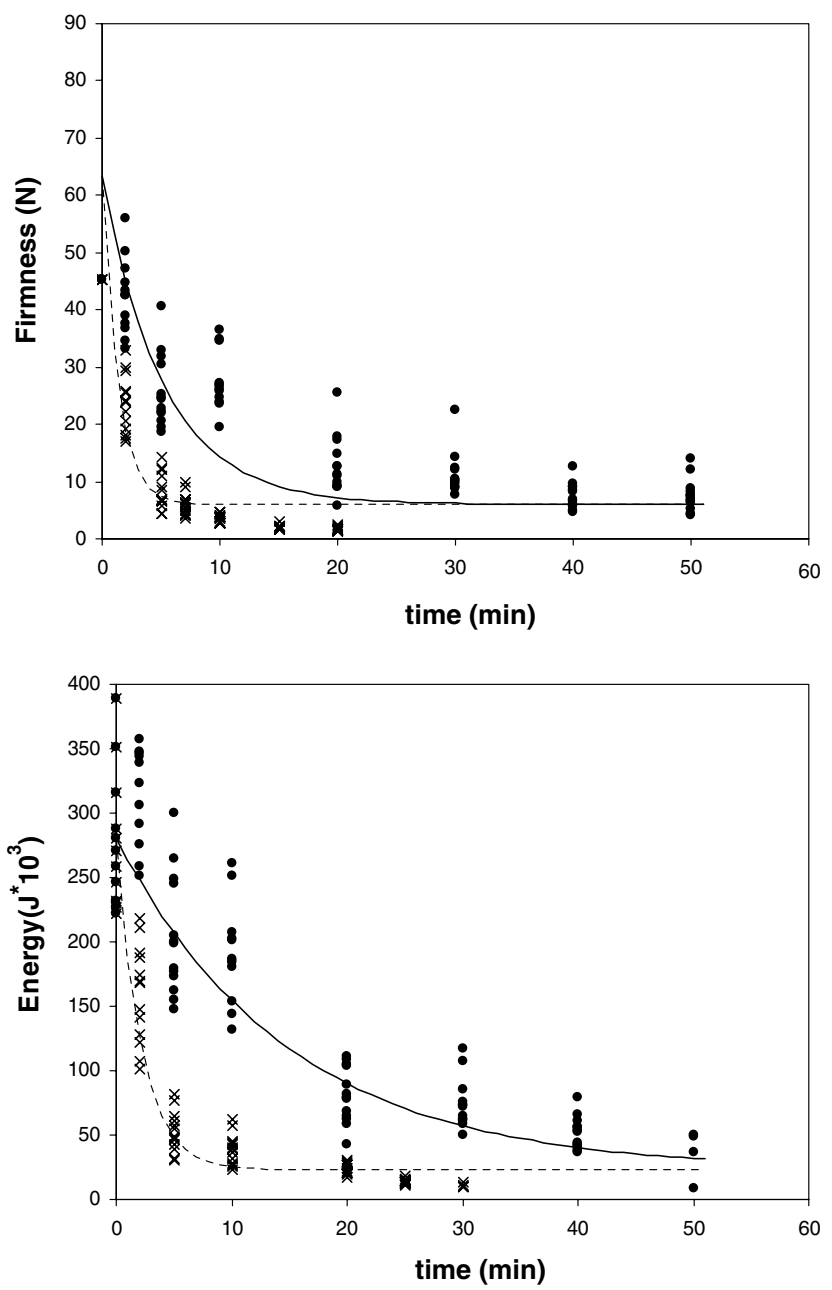

Fig. 4. Pumpkin texture changes (firmness and energy) during blanching process ( experimental data at $75^{\circ} \mathrm{C} ; \times$ experimental data at $95^{\circ} \mathrm{C}$ ). The lines represent model fits (Eqs. (4) and (5) one-step) to experimental data.

tion of texture for the blanching pumpkin processes (kinetic parameters included in Table 2). Estimated activation energies for firmness and energy, 72.2 and 101.9 $\mathrm{kJ} \mathrm{mol}^{-1}$ respectively, fall in the range reported for beans, potatoes, green asparagus and carrots (Table 1).

If blanching conditions for $90 \%$ of peroxidase inactivation were used, only $14 \%$ of pumpkin firmness and $25 \%$ of energy would be retained.

\section{Conclusion}

Peroxidase in blanched pumpkin follows a first-order inactivation kinetics. The other quality factors analysed (colour and texture) were well described by a fractional conversion model. The Arrhenius model described the temperature dependence of the reaction rate constant of all the factors considered.

Modelling the kinetics of peroxidase inactivation and colour and texture changes of pumpkin during blanching will allow convenient thermal processes to be developed that stabilize the products enzymatic deterioration and, 
simultaneously, minimise important quality losses. Blanching conditions, $5.8 \mathrm{~min}$ at $90{ }^{\circ} \mathrm{C}$ and $3.9 \mathrm{~min}$ at $95^{\circ} \mathrm{C}$, are recommended to decrease $90 \%$ of peroxidase activity, ensuring a good retention of colour factors $(80-75 \%$ for $L^{*}, 62-52 \%$ for $a^{*}$ and $73-68 \%$ for $\left.b^{*}\right)$. Unavoidably, texture is greatly affected (approximately $14 \%$ of firmness and $25 \%$ of energy were retained). However, since the most common final utilisation for this type of product will be the preparation of a base for soups or desserts, texture is not a very determinant quality factor.

\section{Acknowledgements}

Author T.R.S. Brandão acknowledges financial support to Fundação para a Ciência e a Tecnologia (Portugal), via a Post-Doctoral fellowship (SFRH/BPD/11580/2002). All authors acknowledge financial support through Programa Operacional para a Agricultura e o Desenvolvimento Rural-Project AGRO no. 822 (Novas Tecnologias de Processamento de Hortofrutícolas Congelados-EMERCON).

\section{References}

Ahmed, J., Shivhare, U. S., \& Raghavan, G. S. V. (2000). Rheological characteristics and kinetics of colour degradation of green chilli puree. Journal of Food Engineering, 44(4), 239-244.

Anthon, G. E., \& Barrett, D. M. (2002). Kinetic parameters for the thermal inactivation of quality-related enzymes in carrots and potatoes. Journal of Agricultural and Food Chemistry, 50(14), 4119-4125.

Anthon, G. E., Sekine, Y., Watanabe, N., \& Barrett, D. M. (2002). Thermal inactivation of pectin methylesterase, polygalacturonase, and peroxidase in tomato juice. Journal of Agricultural and Food Chemistry, 50(21), 6153-6159.

Aparicio-Cuesta, M. P., Mateos-Notario, M. P., \& Rivas-Gonzalo, J. C. (1992). Sensory evaluations and changes in peroxidase activity during storage of frozen green beans. Journal of Food Science, 57(5), 1129-1131, 1143.

Arabshahi, A., \& Lund, D. (1985). Considerations in calculating kinetic parameters from experimental data. Journal of Food Process and Engineering, 7, 239-251.

Ávila, I. M. L. B., \& Silva, C. L. M. (1999). Modelling kinetics of thermal degradation of colour in peach puree. Journal of Food Engineering, $39(2), 161-166$.

Bahçeci, K. S., Serpen, A., Gökmen, V., \& Acar, J. (2005). Study of lipoxigenase and peroxidase as indicator enzymes in green beans: change of enzyme activity, ascorbic acid and chlorophylls during frozen storage. Journal of Food Engineering, 66(2), 187-192.

Bao, B., \& Chang, K. C. (1994). Carrot juice color, carotenoids, and nonstarchy polysaccharides as affected by processing conditions. Journal of Food Science, 59(6), 1155-1158.

Barreiro, J. A., Milano, M., \& Sandoval, A. J. (1997). Kinetics of colour changes of double concentrated tomato paste during thermal treatments. Journal of Food Engineering, 33(3-4), 359-371.

Barret, D. M., \& Theerakulkait, C. (1995). Quality indicators in blanched, frozen, stored vegetables. Food Technology, 49(62), 64-65.

Bifani, V., Inostroza, J., Cabezas, M. J., \& Ihl, M. (2002). Determinacion de parametros cinéticos de peroxidasa y clorofila a en judias verdes (Phaseolus vulgaris cv. Win) y estabilidad del producto congelado. Revista de Quimica Teorica y Aplicada, Febrero, LIX(467), 57-64.

Bonnie, T. Y. P., \& Choo, Y. M. (1999). Oxidation and thermal degradation of carotenoids. Journal of Oil Palm Research, II(1), 62-78.
Bourne, M. C. (1987). Effect of blanch temperature on kinetics of thermal softening of carrots and green beans. Journal of Food Science, 52(3), 667-668, 690.

Canet, W. (1989). Quality and stability of frozen vegetables. In S. Thorne (Ed.). Developments in food preservation (Vol. 5). New York: Elsevier Science Publishing Inc..

Chang, C. Y., Lai, L. R., \& Chang, W. H. (1995). Relationships between textural changes and the changes in linkages of pectic substances of sweet pepper during cooking processes, and the applicability of the models of interactions between pectin molecules. Food Chemistry, 53(4), 409-416.

Cinar, I. (2004). Carotenoid pigment loss of freeze-dried plant samples under different storage conditions. Lebensmittel-Wissenschaft undTechnologie, 37(3), 363-367.

Cruz, R. M. S., Vieira, M. C., \& Silva, C. L. M. (2006). Effect of heat and thermosonication treatments on peroxidase inactivation kinetics in watercress (Nasturtium officinale). Journal of Food Engineering, 72(1), $8-15$.

Drlange (1994). Colour review. Drlange Application Report No. 8.Oe. Drlange, USE.

Francis, F. J., \& Clydesdale, F. M. (1975). Food colorimetry: Theory and applications. Westport, CT: AVI Publ. Co., 477p.

Galindo, F. G., Toledo, R. T., \& Sjöholm, I. (2005). Tissue damage in heated carrot slices. Comparing mild hot water blanching and infrared heating. Journal of Food Engineering, 67(4), 381-385.

Ganthavorn, C., Nagel, C. W., \& Powers, J. R. (1991). Thermal inactivation of asparagus lipoxigenase and peroxidase. Journal of Food Science, 56(1), 47-49.

Garrote, R. L., Luna, J. A., Silva, E. R., \& Bertone, R. A. (1987). A research note: prediction of residual peroxidase activity in the blanching-cooling of corn-on-the-cob and its relation to off-flavour development in frozen storage. Journal of Food Science, 52(1), 232-235.

Greve, L. C., Shackel, K. A., Ahmadi, H., McArdle, R. N., Gohlke, J. R., \& Labavitch, J. M. (1994). Impact of heating on carrot firmness: contribution of cellular turgor. Journal Agriculture and Food Chemistry, 42, 2896-2899.

Günes, B., \& Bayindirli, A. (1993). Peroxidase and lipoxygenase inactivation during blanching of green beans, green peas and carrots. Lebensmittel-Wissenschaft und-Technologie, 26(5), 406-410.

Halpin, B. E., \& Lee, C. Y. (1987). Effect of blanching on enzyme activity and quality changes in green peas. Journal of Food Science, 52(4), 1002-1005.

Hill, C. G., \& Grieger-Block, R. A. (1980). Kinetic data: generation, interpretation and use. Food Technology, 34(2), 56-66.

Howard, L. A., Wong, A. D., Perry, A. K., \& Klein, B. P. (1999). $\beta$ Carotene and ascorbic acid retention in fresh and processed vegetables. Journal of Food Science, 64(5), 929-936.

Huang, Y. T., \& Bourne, M. C. (1993). Kinetics of thermal softening of vegetables. Journal of Texture Studies, 14, 1-9.

Kleinschmidt, M. G. (1971). Fate of Di-syston (0,0-diethyl S-[2-(ethylthio)ethyl] phosphorodithioate) in potatoes during processing. Journal of Agriculture and Food Chemistry, 19(6), 1196-1197.

Kozempel, M. F. (1988). Modelling the kinetics of cooking and precooking potatoes. Journal of Food Science, 53(3), 753-755.

Lau, M. H., Tang, J., \& Swanson, B. G. (2000). Kinetics of textural and color changes in green asparagus during thermal treatments. Journal of Food Engineering, 45(4), 231-236.

Ling, A. C., \& Lund, D. B. (1978). Determining kinetic parameters for thermal inactivation of heat-resistant and heat-labile isozymes from thermal destruction curves. Journal of Food Science, 43, 1307-1310.

Lund, D. B. (1983). Considerations in modelling food processes. Food Technology, 37(1), 92-94.

MacDougall, D. B. (2002). Colour in food. Improving quality. Cambridge, England: Woodhead Publishing Limited.

Martins, R. C., \& Silva, C. L. M. (2002). Modelling colour and chlorophyll losses of frozen green beans (Phaseolus vulgaris, L). International Journal of Refrigeration, 25(7), 966-974. 
Minolta (1994). Precise colour communication: colour control from feeling to instrumentation. Minolta report, Japan.

Morales-Blancas, E. F., Chandia, V. E., \& Cisneros-Zevallos, L. (2002). Thermal inactivation kinetics of peroxidase and lipoxygenase from broccoli, green asparagus and carrots. Journal of Food Science, 67(1), $146-154$.

Muftugil, N. (1986). Effect of different types of blanching on the color and the ascorbic acid and chlorophyll contents of green beans. Journal of Food Processing and Preservation, 10(1), 69-77.

Murcia, M. A., López-Ayerra, B., \& Garcia-Carmona, F. (1999). Effect of processing methods and different blanching times on broccoli: proximate composition and fatty acids. Lebensmittel-Wissenschaft undTechnologie, 32(4), 238-243.

Oboh, G. (2005). Effect of blanching on the antioxidant properties of some tropical green leafy vegetables. Lebensmittel-Wissenschaft und-Technologie, 38(5), 513-517.

Paulus, K., \& Saguy, I. (1980). Effect of heat treatment on the quality of cooked carrots. Journal of Food Science, 45, 239-241, 245.

Préstamo, G., Fuster, C., \& Risueno, M. C. (1998). Effects of blanching and freezing on the structure of carrots cells and their implications for food processing. Journal of the Science of Food and Agriculture, 77(2), 223-229.

Quast, D. G., \& Da Silva, S. D. (1977). Temperature dependence of the cooking rate of dry legumes. Journal Food Science, 42(2), 370-374.

Rizvi, A. F., \& Tong, C. H. (1997). Fractional conversion for determining texture degradation kinetics of vegetables. Journal of Food Science, $62(1), 1-7$.

Selman, J. D. (1994). Vitamin retention during blanching of vegetables. Food Chemistry, 49(2), 137-147.

Shams, M. A., \& Thompson, D. R. (1987). Qualitative determination of pea losses as affected by conventional water blanching. Journal of Food Science, 52(4), 1006-1009.

Sims, C. A., Balaban, M. O., \& Matthews, R. F. (1993). Optimization of carrot juices and cloud stability. Journal of Food Science, 58(5), $1129-1131$.

Smout, C., Sila, D. N., Vu, T. S., Van Loey, A. M. L., \& Hendrickx, M. E. G. (2005). Effect of preheating and calcium pre-treatment on pectin structure and thermal texture degradation: a case study on carrots. Journal of Food Engineering, 67(4), 419-425.

Soysal, C., \& Soylemez, Z. (2005). Kinetics and inactivation of carrot peroxidase by heat treatment. Journal of Food Engineering, 68(3), 349-356.

Stata Corporation (1999). Stata statistical software: Release 6.0 College Station.

Steet, J. A., \& Tong, C. H. (1996). Degradation kinetics of green color and chlorophylls in peas by colorimetry and HPLC. Journal of Food Science, 61(5), 924-931.

Stoneham, T. R., Lund, D. B., \& Tong, C. H. (2000). The use of fractional conversion technique to investigate the effects of testing parameters on texture degradation kinetics. Journal of Food Science, 65(6), 968-973.

Szczesniak, A. S. (2002). Texture is a sensory property. Food Quality and Preference, 13(4), 215-225.

Tijskens, L. M. M., Schijvens, E. P. H. M., \& Biekman, E. S. A. (2001). Modelling the change in colour of broccoli and green beans during blanching. Innovative Food Science \& Emerging Technologies, 2(4), 303-313.

Van Loey, A., Fransis, A., Hendrickx, M., Maesmans, G., \& Tobback, P. (1995). Kinetics of quality changes of green peas and white beans during thermal processing. Journal of Food Engineering, 24(3), 361-377.

Vu, T. S., Smout, D. N., Sila, D. N., LyNguyen, B., Van Loey, A. M. L., \& Hendrickx, M. E. G. (2004). Effect of preheating on thermal degradation kinetics of carrot texture. Innovative Food Science and Emerging Technologies, 5, 37-44.

Waldron, K. W., Parker, M. L., \& Smith, A. C. (2003). Plant cell walls and food quality. Comprehensive Reviews in Foods Science and Food Safety, 2(1), 101-119.

Weinstein, J. S., Vogt, T. M., \& Gerrior, S. A. (2004). Healthy eating index scores are associated with blood nutrient concentrations in the third National Health and Nutrition Examination Survey. Journal of the American Dietetic Association, 104(4), $576-584$. 